also of the gift by Mr. Fry of a smaller instrument, an 8-in. refractor by Cooke. The Astronomer Royal described the Radcliffe telescope as a sister telescope to the one now being used at Greenwich for parallax determinations, and hoped that much useful work along similar lines would be done in the future at Mill Hill, in keeping with the past traditions of the Radeliffe Observatory. The Radcliffe Observatory has now been removed to Pretoria, where the largest telescope in the southern hemisphere is being erected. The Vice-Chancellor, Sir Robert Pickard, thanked the Astronomer Royal on behalf of the University for performing the opening ceremony.

\section{Museums and Rural Life}

IN supporting the appeal for a further $£ 5,000$ for the endowment fund which was launched at the jubilee celebrations of the Haslemere Educational Museum, Dr. John Ramsbottom, president of the Linnean Society, stressed the great importance of teaching people of all classes how best to spend their leisure. The Haslemere Museum, he said, is worthy of unreserved praise, for it is part of the communal life of the district. Children and adults bring specimens of all kinds to the Museum for identification and are assured of receiving information, whether it be a matter of local history or natural history. He also referred to the magnificent display of British wild flowers with their names and such information as is sure to appeal, that is maintained in the Museum throughout the year. Lord Winterton suggested that research into the origin of the old wageearning families in the neighbourhood of Haslemere would prove most interesting, for many of them are descended from migrants from France or Flanders in the fourteenth and fifteenth centuries. During that time there was a big trade between the Sussex and Hampshire ports with France and considerable migration between the two countries; also large numbers of workers came over for the extensive glass industry then existing in the south of England. In those days, when anyone made any money, it was put into land, and many of the place names-such as those of the woods, fields and so on in the neighbourhood-give indications of the names of the worker-immigrants, some of them also being of Saxon origin.

\section{Linnæus in England}

The Year Book of the Swedish Linnean Society for 1938 (Svenska Linné-Sällskapets Årsskrift, Årg. 21) opens with a dedication to the Linnean Society of London on the occasion of its sesqui-centenary, in which the elder Society is greeted as "chirographorum Caroli Linnaei pia conservatrix". The volume contains a long account, illustrated by photographs and drawings, of Linnæus's house in the old Botanical Gardens at Uppsala and of the way in which it has now been skilfully restored as nearly as possible to the state in which it was when Linnæus lived in it. Of the other articles one, by the editor, Mr. A. Hj. Uggla, is of special interest to readers in Great Britain, since it deals with two recently discovered documents bearing on Linnæus's connexion with
England. One is a draft of a letter intended for, and perhaps actually sent to, Dillenius at Oxford in 1733, when Linnæus was twenty-five years old, and shortly after his expedition to Lapland. It is written in Latin and ends by expressing the hope that he might one day meet Dillenius. This hope was fulfilled when Linnæus visited Oxford three years later. The other document is a letter written in August 1735 by J. F. Gronovius in Leyden to Philip Miller, superintendent of the Apothecaries' Garden at Chelsea. It is written in English and states that Linnæus, then in Leyden, "hath a mind to make a step over to England to be acquainted with you. . . . I am sure you will be pleased with his company, but it will bee troublesome for him as only speaking his own Language and Latin, however $I$ think the Swedish minister at London can procure him an interpreter".

\section{Experimental Fire-Walks}

A RePort by Dr. G. Burniston Brown on three experimental fire-walks has recently been issued ("A Report on Three Experimental Fire-Walks by Ahmed Hussain and others". By Dr. G. Burniston Brown. Bull. 4. University of London Council for Psychical Investigation, 19 Berkeley Street, Mayfair, London, W.1. 1s. net). The experiments were made at Carshalton, where Kuda Bux had also been tested (see NATURE, 136, 468, 521; 1935) and at the Alexandra Palace. The accompanying table shows a comparison of the most successful attempts made by Ahmed Hussain, R. Adcock and Kuda Bux.

\begin{tabular}{|c|c|c|c|c|c|c|}
\hline & Weight & $\begin{array}{c}\text { Distance } \\
\text { walked }\end{array}$ & $\begin{array}{c}\text { Surface } \\
\text { temp. }\left({ }^{\circ} \mathrm{C} .\right)\end{array}$ & $\begin{array}{l}\text { No. of } \\
\text { steps }\end{array}$ & Time & $\begin{array}{c}\text { Minimum } \\
\text { mean time } \\
\text { of contact } \\
\text { per step }\end{array}$ \\
\hline $\begin{array}{l}\text { Hussain } \\
\text { Adcock } \\
\text { Kuda Bux }\end{array}$ & $\begin{array}{l}126 \mathrm{lb} . \\
160 \%, \\
120,\end{array}$ & $\begin{array}{l}12 \mathrm{ft} . \\
12 ", \\
11 \text { ", }\end{array}$ & $\begin{array}{l}800^{\circ} \\
800^{\circ} \\
430^{\circ}\end{array}$ & $\begin{array}{l}4 \\
3 \\
4\end{array}$ & $\begin{array}{l}1.6 \text { sec. } \\
1.8 \quad ", \\
2.2 \quad,\end{array}$ & $\begin{array}{l}0 \cdot 40 \\
0 \cdot 60 \\
0 \cdot 55\end{array}$ \\
\hline
\end{tabular}

The results of the experiment showed that the firewalk is not a trick, but is performed in the normal manner with bare and chemically untreated feet. Moisture on the feet was shown to be a disadvantage, since it may cause hot particles to adhere to the skin and thus cause blisters. The sudden formation of an insulating cushion of vapour between the foot and the hot embers does not occur, and no abnormal degree of callosity of the feet is required.

\section{The "Invisible College", I645-1662}

IN the Moravian literary publication, Miscellanea, Dr. R. F. Young recently gave an account of the "Invisible College" which preceded the foundation of the Royal Society in 1662. The term was used to describe the periodical meetings of men of science at either London or Oxford, and Dr. Young points out that the contemporary meaning may have been derived in four possible ways. In the first place, it may be an Italian concetto adopted directly by Boyle from the name of a literary academy at Cremona. It may have been borrowed from the contemporary critics and opponents of the "invisible" Rosicrucians, such as J. V. Andreae (1586-1654). A third view is that it was a reminiscence of an elaborate play on 